\title{
Pengaruh Model Pembelajaran Kooperatif Tipe Stad dan Motivasi Belajar terhadap Hasil Belajar Bahasa Indonesia
}

\author{
Dina Indri Astuti \\ Universitas Indraprasta PGRI \\ Jalan Nangka No. 58 C/TB. Simatupang, Tanjung Barat, Jakarta Selatan 12530 \\ indriastuti.dina@gmail.com
}

\begin{abstract}
The purpose of this study was to determine the effect of STAD type cooperative learning models and learning motivation on Indonesian learning outcomes. The population is grade VIII students in SMPN 1 Pedes and SMPN 2 Pedes in the Academic Year 2018/2019. The research sample consisted of 30 students of class VIII-A as an experimental class using the STAD type cooperative learning model consisting of two groups, namely high motivation and low motivation, while class VIII-D numbered 30 students as a control class using conventional learning models consisting from two groups, namely high motivation and low motivation. Data were collected with a questionnaire for learning motivation and with tests for learning outcomes in Indonesian. Data analysis using twoway ANOVA technique. The results showed that 1) there were differences in Indonesian learning outcomes between students who took the STAD type cooperative learning model and those who followed the conventional learning model, 2) there was an interaction effect between the STAD type cooperative learning models and learning motivation on Indonesian learning outcomes, where STAD type cooperative learning models are superior to conventional learning models. Thus, it can be concluded that the STAD type of cooperative learning model and learning motivation have a significant effect on Indonesian language learning outcomes in SMPN students in Karawang.
\end{abstract}

Keywords: STAD Type Cooperative Learning Model, Learning Motivation, and Indonesian Language Learning Outcomes.

\begin{abstract}
Abstrak
Tujuan penelitian ini untuk mengetahui pengaruh model pembelajaran kooperatif tipe STAD dan motivasi belajar terhadap hasil belajar Bahasa Indonesia. Populasinya siswa kelas VIII di SMPN 1 Pedes dan SMPN 2 Pedes Tahun Ajaran 2018/2019. Sampel penelitian berjumlah 30 siswa kelas VIII-A sebagai kelas eksperimen dengan menggunakan model pembelajaran kooperatif tipe STAD yang terdiri dari dua kelompok, yaitu motivasi tinggi dan motivasi rendah, sedangkan kelas VIII-D berjumlah 30 siswa sebagai kelas kontrol dengan menggunakan model pembelajaran konvensional yang terdiri dari dua kelompok, yaitu motivasi tinggi dan motivasi rendah. Data dikumpulkan dengan kuesioner untuk motivasi belajar dan dengan tes untuk hasil belajar bahasa Indonesia. Analisis data menggunakan teknik ANOVA dua arah. Hasil penelitian menunjukkan bahwa 1) terdapat perbedaan hasil belajar bahasa Indonesia antara siswa yang mengikuti model pembelajaran kooperatif tipe STAD dengan yang mengikuti model pembelajaran konvensional, 2) terdapat pengaruh interaksi antara model pembelajaran kooperatif tipe STAD dan motivasi belajar terhadap hasil belajar Bahasa Indonesia, di mana model pembelajaran kooperatif tipe STAD lebih unggul daripada model pembelajaran konvesional. Dengan demikian, dapat disimpulkan bahwa model pembelajaran kooperatif tipe STAD dan motivasi belajar berpengaruh signifikan terhadap hasil belajar Bahasa Indonesia pada siswa SMPN di Karawang.
\end{abstract}

Kata Kunci: Model Pembelajaran Kooperatif Tipe STAD, Motivasi Belajar, dan Hasil Belajar Bahasa Indonesia

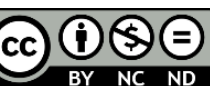

Creative Commons Attribution-NonCommercial-NoDerivatives 4.0 International License 


\section{PENDAHULUAN}

Pendidikan harus mampu mengembangkan potensi-potensi spiritual, sosial, pengetahuan, dan keterampilan yang dimiliki siswa, sehingga siswa memiliki kecerdasan untuk menyelesaikan berbagai permasalahan kehidupan yang dihadapi sekarang dan masa depan. Proses pembelajaran di sekolah merupakan bagian dari pencapaian tujuan pendidikan nasional. Oleh karena itu, sekolah harus mampu meningkatkan mutu pendidikan, melakukan pembenahan dari segi model pembelajaran, materi, dan evaluasi pembelajaran sehingga mampu menyiapkan siswa untuk menghadapi berbagai persoalan di masyarakat.

Kurikulum yang digunakan saat ini mengacu pada kurikulum 2013. Ada empat faktor yang menjadi alasan pengembangan kurikulum 2013, yaitu: pertama, tantangan masa depan meliputi masalah lingkungan hidup, kemajuan teknologi informasi, globalisasi, konvergensi ilmu dan teknologi, dan ekonomi berbasis pengetahuan. Kedua, kemampuan menjadi warga negara yang efektif, kemampuan untuk toleransi dan mengerti terhadap pandangan yang berbeda, kemampuan berpikir jernih dan kritis, dan kemampuan mempertimbangkan segi moral suatu permasalahan. Ketiga, fenomena sosial seperti perkelahian pelajar, narkoba, dan gejolak sosial. Keempat, persepsi masyarakat yang menilai pendidikan lebih condong pada aspek kognitif, beban materi pelajaran yang terlalu berat, dan kurang bermuatan karakter (Trianto, 2014:4). Jadi, kurikulum 2013 menyeimbangkan dan meningkatkan kompetensi sikap, pengetahuan, dan keterampilan.

Kenyataan yang terjadi saat ini pembelajaran di sekolah masih berpusat kepada guru, sehingga siswa menjadi pasif. Pembelajaran masih bersifat konvensional. Proses pembelajaran hanya didominasi oleh guru, siswa tidak diberikan akses untuk mandiri dan berkembang melalui penemuan dalam proses berpikirnya. Pada pembelajaran yang berpusat kepada guru, guru berceramah menjelaskan konsep yang ada pada buku ajar, siswa mendengarkan penjelasan guru, siswa tidak diajarkan strategi belajar untuk memahami konsep dan kurang termotivasi. Perlu diingat bahwa pendidikan yang bermutu terletak pada pelaksanaan pembelajaran dan penilaian pembelajaran yang bermutu, maka peranan guru untuk menciptakan proses belajar mengajar yang inovatif akan mempengaruhi kualitas hasil belajar siswa.

Penelitian ini bertujuan untuk mengetahui 1) pengaruh model pembelajaran kooperatif tipe STAD terhadap hasil belajar Bahasa Indonesia, 2) pengaruh motivasi belajar terhadap hasil belajar Bahasa Indonesia, 3) pengaruh interaksi model pembelajaran kooperatif tipe STAD dan motivasi belajar terhadap hasil belajar Bahasa Indonesia.

Model pembelajaran kooperatif tipe STAD (Student Teams-Achievement Division) merupakan salah satu tipe dari model pembelajaran kooperatif yang menggunakan kelompok kecil dengan anggota kelompok empat hingga lima orang secara heterogen. Diawali dengan guru menyajikan pelajaran, siswa bekerja dalam tim, dan memastikan bahwa setiap anggota kelompok dapat menguasai pelajaran kuis dikerjakan secara mandiri, serta adanya penghargaan kelompok (Slavin, 2015: 143). 
Langkah-langkah pembelajaran kooperatif tipe STAD terdiri dari enam langkah atau fase, yaitu: 1) menyampaikan tujuan dan memotivasi siswa, 2) menyajikan/menyampaikan informasi, 3) mengorganisasikan siswa dalam kelompok belajar, 4) membimbing kelompok bekerja dan belajar, 5) evaluasi, dan 6) memberikan penghargaan (Trianto, 2014: 121).

Slavin (2015: 100) dalam penelitiannya telah menunjukkan bahwa pembelajaran kooperatif memberikan tujuan penting, yaitu meningkatkan pencapaian prestasi para siswa, cara untuk menciptakan kegembiraan, menciptakan lingkungan yang pro-sosial, memperluas perkembangan interpersonal, dan keefektifan sehingga pemahaman akan perbedaan latar belakang kehidupan dapat memberikan pemahaman yang dibutuhkan supaya menjadi anggota masyarakat yang baik dan bermanfaat di lingkungannya. Jadi, model pembelajaran kooperatif tipe STAD merupakan model pembelajaran yang dibentuk dalam kelompok kecil yang heterogen supaya efektif dalam memecahkan masalah dan masing-masing anggota kelompok saling membantu, menghormati, menghargai, serta saling bekerja sama untuk pencapaian tujuan pembelajaran dengan gembira.

Motivasi belajar merupakan dorongan untuk berperilaku tertentu agar mendapatkan penguatan dan imbalan positif (Sumantri, 2015: 380). Imbalan positif ini dapat meningkatkan hasil belajar siswa. Peranan motivasi belajar antara lain sebagai penggerak jiwa yang ada dalam diri siswa untuk menimbulkan kemauan dalam belajar sehingga tujuan belajar tercapai, menumbuhkan gairah, semangat, dan rasa senang belajar sehingga siswa giat belajar (Eveline dan Nara, 2015: 51).

W. S. Winkel (dalam Sumantri 2015: 381) membagi motivasi menjadi dua jenis, yaitu 1) motivasi intrinsik, merupakan dorongan dari dalam diri individu untuk melakukan sesuatu, 2) motivasi ekstrinsik, dorongan untuk melakukan sesuatu karena adanya rangsangan dari luar diri individu. Motivasi diri dapat bangkit dari keinginan diri untuk meraih hasil belajar sebaik-baiknya, sedangkan motivasi ekstrinsik dapat dirangsang dengan cara guru dalam mengelola pembelajaran di kelas. Jadi motivasi belajar merupakan dorongan dari dalam diri dan rangsangan dari luar diri siswa untuk menumbuhkan kemauan, gairah, semangat, kegembiraan belajar sehingga tujuan belajar tercapai dan hasil belajar meningkat.

\section{METODE}

Penelitian ini dilakukan di SMP Negeri Karawang, yaitu SMPN 1 Pedes dan SMPN 2 Pedes. Populasinya semua siswa kelas VIII Tahun Ajaran 2018/2019. Teknik sampling menggunakan random sampling dan menentukan kelas eksperimen dan kelas kontrol. Sampel yang digunakan sebagai kelas eksperimen dan kelas kontrol berjumlah tiga puluh siswa yang terbagi menjadi dua kelompok, yaitu motivasi tinggi dan motivasi rendah.

Penelitian ini menggunakan desain penelitian faktorial 2x2 (Supardi, 2016: 350). Pada eksperimen ini tentang model pembelajaran cara pertama (A1), yakni model pembelajaran kooperatif tipe STAD dan cara kedua (A2) dengan model pembelajaran konvensional, pada siswa dengan motivasi belajar tinggi (B1) dan

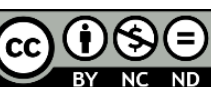


siswa dengan motivasi belajar rendah (B2), karena ada du acara pada masingmasing variable maka disebut dengan $2 \times 2$ factorial design.

Hasil uji validitas butir soal pilihan ganda tes hasil belajar menggunakan korelasi point biserial (Supardi, 2016: 117) terhadap tiga puluh butir instrument tes yang dilakukan pada tiga puluh siswa diperoleh 21 butir dinyatakan valid, dan 9 butir tidak valid. Hasil pengujian diperoleh reliabilitas dengan menggunakan rumus Kuder Richardson= 0,705.

Pengujian validitas kuesioner motivasi belajar menggunakan rumus Pearson Correlation, dari 40 butir instrument motivasi belajar diperoleh 23 butir valid dan 17 butir tidak valid. Reliabilitas=0,723 dengan menggunakan rumus Alpha Cronbach.

\section{HASIL DAN PEMBAHASAN}

\section{Hasil}

Data hasil penelitian dianalisis dengan teknik statistik deskriptif untuk mengukur tendensi sentral dan tendensi penyebaran data dari setiap kelompok. Perhitungan data hasil penelitian dilakukan dengan menggunakan program olah data yaitu SPSS versi 20. Uji prasyarat analisis meliputi uji normalitas sebaran data (metode Kolmogorov-Smirnov) dan uji homogenitas varian (metode Levene's Test). Hasil uji normalitas dengan nilai signifikan $0,115>0,05$. Hasil tes homogenitas nilai signifikan sebesar 0,199>0,05, sehingga disimpulkan semua kelompok data memiliki varian yang homogen.

Hasil pengujian hipotesis dapat dideskripsikan sebagai berikut. Hipotesis pertama berbunyi terdapat pengaruh signifikan model pembelajaran kooperatif tipe STAD terhadap hasil belajar Bahasa Indonesia. Berdasarkan hasil pada tabel 1 Tes Uji Hipotesis ANOVA 2 Arah menunjukkan F hitung = 9,443 Sig. untuk model pembelajaran 0,004 $<0,05$. Jadi simpulannya terdapat pengaruh signifikan model pembelajaran terhadap hasil belajar Bahasa Indonesia.

Hipotesis kedua berbunyi terdapat pengaruh signifikan motivasi belajar terhadap hasil belajar Bahasa Indonesia. Berdasarkan hasil pada tabel 1 Tes Uji Hipotesis ANOVA 2 Arah menunjukkan F hitung $=8,313$ Sig. untuk motivasi belajar 0,007 < 0,05. Jadi simpulannya terdapat pengaruh signifikan motivasi belajar terhadap hasil belajar Bahasa Indonesia.

Hipotesis ketiga berbunyi terdapat pengaruh interaksi antara model pembelajaran dan motivasi belajar terhadap hasil belajar Bahasa Indonesia. Berdasarkan hasil pada tabel 1 Tes Uji Hipotesis ANOVA 2 Arah menunjukkan F $\mathrm{AB}$ hitung $=4,354 \mathrm{Sig}$. untuk model pembelajaran dan motivasi belajar 0,044< 0,05. Jadi simpulannya terdapat pengaruh interaksi antara model pembelajaran dan motivasi belajar terhadap hasil belajar Bahasa Indonesia.

Berdasarkan uji lanjut dengan uji Tukey. Pada kelompok yang menggunakan model pembelajaran kooperatif tipe STAD antara siswa dengan motivasi tinggi dan motivasi rendah, terlihat bahwa mean difference sebesar 26,20 dan nilai signifikansi $0,006<0,05$. Jadi, simpulannya terdapat perbedaan hasil belajar Bahasa Indonesia antara siswa dengan motivasi tinggi dan motivasi rendah 
yang mengikuti model pembelajaran kooperatif tipe STAD.

Pada kelompok yang menggunakan model pembelajaran kooperatif tipe STAD dengan siswa motivasi tinggi dan kelompok model pembelajaran konvensional dengan siswa motivasi tinggi, terlihat bahwa mean difference sebesar 27,20 dan nilai signifikansi 0,004 < 0,05. Jadi simpulannya terdapat perbedaan hasil belajar Bahasa Indonesia antara siswa motivasi belajar sama-sama tinggi yang mengikuti model pembelajaran kooperatif tipe STAD dengan yang mengikuti model pembelajaran konvensional.

Pada kelompok yang menggunakan model pembelajaran kooperatif tipe STAD dengan siswa motivasi rendah dan kelompok model pembelajaran konvensional dengan motivasi rendah, terlihat bahwa mean difference sebesar 5,20 dan nilai signifikansi 0,897 > 0,05. Jadi simpulannya tidak terdapat perbedaan hasil belajar Bahasa Indonesia antara siswa motivasi belajar sama-sama rendah yang mengikuti model pembelajaran kooperatif tipe STAD dengan yang mengikuti model pembelajaran konvensional.

Pada kelompok yang menggunakan model pembelajaran konvensional antara siswa dengan motivasi tinggi dan rendah, terlihat bahwa mean difference sebesar 4,20 dan nilai signifikansi 0,942 >0,05. Jadi simpulannya tidak terdapat perbedaan hasil belajar Bahasa Indonesia antara siswa dengan motivasi tinggi dan motivasi rendah yang mengikuti model pembelajaran konvensional.

\section{Pembahasan}

Temuan penelitian ini seirama dengan teori yang dikemukakan oleh Slavin (2005: 105) bahwa penggunaan model pembelajaran kooperatif tipe STAD dapat mempererat hubungan pertemanan dan meningkatkan prestasi belajar. Dalam satu kelompok, anggota kelompok saling membantu untuk memecahkan permasalahan yang dihadapi ketika dalam pembelajaran untuk mencapai tujuan pembelajaran. Lebih lanjut Slavin (2005: 129) mengungkapkan bahwa siswa yang belajar menggunakan model kooperatif tipe STAD termotivasi untuk giat belajar karena mereka termotivasi untuk melakukan yang terbaik untuk kelompoknya. Mereka memiliki kesempatan untuk sukses dan sukses adalah tujuan yang bermakna.

Dalam pembelajaran model kooperatif tipe STAD, siswa saling membantu dalam kelompok, saling bekerja sama untuk memahami permasalahan yang ditemukan ketika ada permasalahan dengan berdiskusi. Siswa mencari tahu solusi pemecahan masalahnya sehingga siswa berusaha untuk membangun kembali pemahaman akan suatu masalah dan mencari jalan keluarnya. Di sini siswa saling berbagi pengetahuannya dalam berdiskusi, dan guru mengarahkan serta membimbing siswa untuk mencapai tujuan pembelajaran. Jadi pembelajaran lebih bersifat student center.

Pembelajaran kelompok kooperatif tipe STAD sangat bermakna karena siswa berusaha menemukan pemecahan masalah dengan bekerja sama dalam kelompok. Mereka termotivasi untuk mencapai tujuan pembelajaran karena ada stimulus yang diberikan guru berupa penghargaan/reward. Oleh karena itu, motivasi ekstrinsik merupakan suatu motivasi yang dapat menumbuhkan dan membangkitkan semangat belajar dari luar. Seperti yang diungkapkan Dimyati dalam Sumantri (2015:379) bahwa pemberian motivasi dapat menentukan 
keberhasilan dalam belajar untuk memahami pengetahuan, nilai-nilai, dan keterampilan. Dengan demikian, penerapan model pembelajaran kooperatif tipe STAD dapat meningkatkan hasil belajar. Hasil penelitian ini juga sejalan dengan penelitian terdahulu yang relevan.

Penelitian Adnyani (2014) membuktikan bahwa terdapat perbedaan hasil belajar bahasa Indonesia antara siswa yang mengikuti model pembelajaran kooperatif tipe STAD dengan yang mengikuti model pembelajaran konvensional berpengaruh signifikan pada siswa kelas VIII SMPN 3 Seririt tahun pelajaran 2013/2014.

Penelitian Adnyani ini juga didukung oleh penelitian sebelumnya, seperti penelitian Mulyati (dalam Adnyani, 2014) bahwa ada pengaruh yang signifikan antara penggunaan model STAD dengan model Jigsaw terhadap prestasi belajar IPS. Prestasi belajar dengan menggunakan model STAD ternyata lebih baik dibandingkan prestasi belajar menggunakan model Jigsaw.

Sebaliknya, model konvensional kurang memberikan kesempatan kepada siswa untuk aktif dan mengembangkan proses berpikirnya. Siswa tidak terlatih untuk menemukan pemecahan masalah karena guru telah menunjukkan dan memberikan pemecahan masalahnya sehingga siswa hanya mencatat dan mendengar pengetahuan yang diberikan guru. Guru mendominasi proses pembelajaran/teacher center. Dengan demikian penelitian penulis telah melengkapi temuan-temuan sebelumnya bahwa pembelajaran dengan model kooperatif tipe STAD secara signifikan telah berpengaruh meningkatkan hasil belajar Bahasa Indonesia siswa daripada model konvensional.

Sagala (2012: 223) berpendapat bahwa memilih cara pendekatan belajar mengajar, prosedur, metode, dan teknik mengajar akan berpengaruh pada hasil belajar siswa. Maka guru sedapat mungkin mampu menyesuaikan model pembelajaran yang tepat bagi siswa. Siswa yang memiliki motivasi belajar tinggi, aktif dan mandiri sangat sesuai untuk menggunakan model pembelajaran kooperatif tipe STAD yang memberikan keleluasaan kepada siswa untuk berdiskusi dan bekerja sama dalam kelompok sehingga dapat menemukan pemecahan masalah. Dalam penelitian ini, penulis menemukan bahwa siswa yang memiliki motivasi belajar rendah memiliki hasil belajar yang kurang, bahkan siswa yang memiliki motivasi rendah dengan pilihan model pembelajaran konvensional yang diberikan guru pun menunjukkan hasil belajar kurang. Teori dan penelitian empirik menunjukkan bahwa motivasi belajar mempengaruhi hasil belajar. Siswa yang memiliki motivasi belajar tinggi akan memperoleh hasil belajar yang baik pula. Dengan demikian, hasil penelitian penulis telah melengkapi temuan-temuan pada penelitian sebelumnya yang menyatakan bahwa terdapat pengaruh interaksi antara model pembelajaran dan motivasi belajar terhadap hasil belajar Bahasa Indonesia siswa.

\section{SIMPULAN}

Berdasarkan hasil dari penelitian ini dapat disampaikan simpulan berikut: 1) terdapat pengaruh yang signifikan model pembelajaran kooperatif tipe STAD 
terhadap hasil belajar Bahasa Indonesia dengan sig. $=0,004<0,05$ dan $\mathrm{F}$ hitung $=$ 9,443. 2) terdapat pengaruh yang signifikan motivasi belajar terhadap hasil belajar Bahasa Indonesia dengan sig. 0,007 >0,05 dan $\mathrm{F}$ hitung $=8,313$. 3) terdapat pengaruh interaktif yang signifikan antara model pembelajaran kooperatif tipe STAD dan motivasi belajar terhadap hasil belajar Bahasa Indonesia dengan sig. $0,044<0,05$ dan $\mathrm{F}$ hitung $=4,354$.

Berpedoman pada simpulan di atas, maka disarankan guru memilih dan memilah model pembelajaran dan dapat menjadikan model pembelajaran kooperatif tipe STAD sebagai salah satu cara untuk meningkatkan hasil belajar Bahasa Indonesia.

\section{DAFTAR PUSTAKA}

Adnyani, L. D. S. (2014). Penerapan Teknik Role Play dengan Bantuan Video pada Mata Kuliah Speaking 2 Untuk Meningkatkan Keterampilan Berbicara Mahasiswa Jurusan Pendidikan Bahasa Inggris Undiksha Tahun Ajaran 2011/2012. Jurnal Pendidikan Indonesia, 3(1), 313-325. https://ejournal.undiksha.ac.id/index.php/JPI/article/view/2914.

DOI: http://dx.doi.org/10.23887/jpi-undiksha.v3i1.2914

Eveline, \& Nara, H. (2015). Teori belajar dan pembelajaran. Bogor: Ghalia Indonesia.

Sagala, S. (2012). Konsep dan makna pembelajaran untuk membantu memecahkan problematka belajar dan mengajar. Bandung: Alfabeta.

Slavin, R. E. -Terj. Narulita Yusron. (2015). Cooperative learning teori, riset, dan praktik. Bandung: Penerbit Nusa Media.

Sumantri, M. S. (2015). Strategi pembelajaran: teori dan praktik di tingkat pendidikan dasar. Jakarta: Rajawali Press.

Supardi. (2016). Aplikasi statistik dalam peneitian edisi revisi konsep statistika yang lebih komprehensip. Jakarta: Change Publication.

Trianto. (2014). Mendesain model pembelajaran inovatif, progresif, dan kontekstual: konsep, landasan, dan implementasinya pada kurikulum 2013 (kurikulum tematik integratif/tki). Jakarta: Prenadamedia Group. 